Diabetologia 7, 302-307 (1971)

(c) by Springer-Verlag 1971

\title{
Plasma Growth Hormone in the New Zealand Obese Mouse
}

\author{
R. G. LaRKTNS \\ University of Melbourne Department of Medicine, Royal Melbourne Hospital, Victoria, Australia
}

Received: April 18, 1971, accepted: June 14, 1971

Summaty. Plasma growth hormone was measured by radioimmunoassay under basal conditions and after glucose administration in the New Zealand Obese (NZO) mouse and in a control strain. 'There was greater variabili. ty of plasma IRGH in the NZO mice than in the control strain under basal conditions, but there was no significant difference between the mean log plasma IRGH in the two strains. Moreover, in both strains rapid suppression of plasma TRGH occurred following glucose administration. It appears unlikely that pituitary hypersecretion of growth hormone accounts for the metabolic abnormalities observed in the NZO mouse.

L'hormone de croissance plasmatique chez la souris obèse de la Nouvelle-Zélande

Résumé. L'hormone de croissance immunoréactive (IRGH) plasmatique a été mesuréo par une méthode radio-immunologique dans des conditions de base et après l'administration de glucose chez la souris obèse de la Nouvelle-Zélande (NZO) et aussi cher une souche de souris témoins. On a constaté plus de variabilité de IRGH plasmatique chez la souris $\mathrm{NZO}$ que chez la souche de souris tếmoins dans les conditions de base, mais il $n^{\prime} y$ avait pas de différence notable entre la moyenne logá rithmique de IRGH plasmatique dans les deux souches de souris. D'ailleurs dans toutes les deux races il y avait une suppression rapide de IRGH plasmatique après l'administration de glucose. Il paraitt peu probable que l'hypersécrétion pituitaire de l'hormone de croissance explique les anomalies métaboliques observées chez la souris NZO.

Das Plasma-Wachstumshormon bei der New Zealand Obese mouse

Zrusammenfassung: Das Wachstumshormon in Plasma wurde unter Anwendung der Radioimmunomethode unter basalen Bedingungen und nach Zufuhr von Glucose bei der New Zealand obese mouse (NZO) und einer Kontrollzucht gemessen. Unter basalen Bedingungen bestand bei den NZO-Mäusen eine größere Variabilität des immun. reaktiven Wachstumshormons im Plasma (IRGH) als bei der Kontrollzucht; es fand sich jedoch kein wesentlicher Unterschied des mittleren logarithmischen Plasma IRG.H bei den beiden Zuchten. Darüberhinaus erfolgte nach Zufuhr von Glucose bei beiden Zuchten eine schnelle Sup. pression des Plasma-IRGH. Es ist unwahrscheinlich, daB die pituitäre Hypersekretion des Wachstumshormons für die metabolisehen Anomalien bei der NZO-Maus verantwortlich zu machen ist.

Key-words: NZO mouse, plasma growth hormone, suppression after gluoose.
The New Zealand Obese (NZO) mouse is one of a number of strains of mice with genetically determined obesity, accompanied by carbohydrate intolerance, insulin resistance and hyperinsulinaemia. M. and F. Bielschowsky who were responsible for breeding this strain [1] suggested that the metabolic disorder might be due to excessive growth hormone activity [2]. More recently, Nakamura [13] and Herbai et al. [6,7] have produced indirect evidence to support this hypothesis in the "KK" and "ob-ob" strains of obese hyperglycaemic mice respectively. So far, no direct measurements of plasma growth hormone have been reported in any of these mice. In this study, the plasma immunoreactive growth hormone (IRGH) was measured in the NZO mouse and in a control strain and the effect of administration of glucose on the plasma IRGH was determined.

\section{Materials and Methods}

NZO mice aged 7 to 42 weeks, and $\mathrm{C}_{57} \mathrm{~B}$ mice used as a control strain aged 7 to 36 weeks were obtained from the Walter and Eliza Hall Institute of Medical
Research, Melbourne. Mice from both strains were maintained under identical conditions with water and dog eubes, which contained fat $5 \%$, protein $20 \%$, carbohydrate $50 \%$ and added vitamins, available $\mathrm{ad}$ libitum.

Blood samples were obtained under light ether anaesthesia from the orbital sinus through heparinized $100 \mu l$ 'Microcap' pipettes. Between 100 and $400 \mu l$ of blood was obtained from each mouse and collected into iced tubes without further heparin. After centrifugation the plasma, was stored at $-15^{\circ} \mathrm{C}$ until assay. To allow for duplicate estimations and "blanks" for each sample, blood from littermates of the same sex was pooled for each growth hormone estimation.

The samples were taken after an overnight fast (6 p.m. to 10 a.m.), and after a $3 \mathrm{~h}$ fast $(9 \mathrm{a} . \mathrm{m}$. to 12 midday). Only adult mice ( $>10$ weeks) were used for these basal determinations. 18 groups of NZO mice (each group containing 2 to 4 littermates of the same sex), age range 14 to 36 weeks (mean 26 weeks) were studied after an overnight fast and 12 groups of $\mathrm{C}_{57} \mathrm{~B}$ mice age range 14 to 36 weeks (mean 27 weeks). The $\mathrm{NZO}$ and $\mathrm{C}_{57} \mathrm{~B}$ mice each contained equal proportions of males and females. After a $3 \mathrm{~h}$ fast, 35 groups 
of NZO mice, age range 11 to 42 weeks (mean 24 weeks) and 17 groups of $\mathrm{C}_{57} \mathrm{~B}$ mice, age range 13 to 36 weeks (mean 24 weeks) were studied.

In other mice, the effect of the administration of glucose on plasma IRGH. was determined. This test was performed on 7 different age groups of $\mathrm{C}_{57} \mathrm{~B}$ mice, age range 7 to 36 weeks (mean 20 weeks) and on 12 different age groups of NZO mice, age range 7 to 42 weeks (mean 27 weeks). Each group contained 2 to 4 littermates of the same sex. The test on each group was performed over 7 days, with two days between successive procedures. On day 1, blood was obtained after a $3 \mathrm{~h}$ fast. On day 3 , after a $3 \mathrm{~h}$ fast, glucose $2 \mathrm{mg} / \mathrm{g}$ was injected intraperitoneally into each animal and blood obtained 5 min later. On days 5 and 7 a similar procedure was followed with blood being obtained at 20 and $40 \mathrm{~min}$ after the injection respectively. Thus on each day, the mice had only one anaesthetic and bleed. Control experiments were performed on 5 groups of $\mathrm{NZO}$ mice and 3 groups of $\mathrm{C}_{57} \mathrm{~B}$ mice using intraperitoneal administration of a similar volume of $0.9 \%$ saline, and otherwise identical conditions.

Blood sugar estimations were performed with a "Technicon Autoanalyser" using a ferricyanide method, adjusted to measure $25 \mu 1$ specimens of blood with an error of $\pm 10 \%$ at 86 and $204 \mathrm{mg} / 100 \mathrm{ml}$.

Plasma IRGH was measured using a radioimmunoassay. Rat growth hormone (NIAMD - Rat GH-RP-1) was used as the standard. A more purified form of rat growth hormone (NIAMD-Rat GII-I-1) was labelled with ${ }^{125} \mathrm{I}$ in a method which was similar to that described by Hunter and Greenwood [8]. $10 \mu \mathrm{g}$ of rat growth hormone, $0.5 \mathrm{mCi}$ of ${ }^{125} \mathrm{I}$ and $70.4 \mu \mathrm{g}$ of chloramine $\mathrm{T}$ were mixed in $0.3 \mathrm{M}$ phosphate buffer, $\mathrm{pH}$ 7.6. 15 seconds later the iodination reaction was stopped by the addition of $240 \mu \mathrm{g}$ of sodium metabisulphite. A cellulose column was used for purification of the tracer, as this proved more satisfactory than Sephadex gel filtration. ${ }^{125}$ I-labelled growth hormone was eluted with $20 \%$ acetone in $1 \%$ human serum albumin-veronal buffer, as described by Yalow and Berson [18]. Rat growth hormone antiserum obtained in monkeys was used (NIAMD-Anti-Rat GH serum 1) at $1: 15000$ concentration. All assays were performed in duplicate, using $50 \mu \mathrm{l}$ samples of mouse plasma. The standard curve was made up in phosphosalinealbumin buffer $\mathrm{pH} 7.6$ with $50 \mu \mathrm{l}$ of human plasma added to each tube. The standard or samples and antiserum were incubated for $48 \mathrm{~h}$ at $4^{\circ} \mathrm{C}$, then tracer was added and further incubation performed for $48 \mathrm{~h}$. The final incubation volume was $500 \mu \mathrm{l}$. Separation of free from bound tracer was performed using dextrancoated charcoal, as described by Jacobs [9], but modified so that $40 \mathrm{mg}$ of charcoal was added to each tube. Correction for non-specific binding of tracer in the mouse plasma was made by including a "blank" without antibody for every plasma sample assayed.

The validity of the assay system was established by dilution and recovery experiments. Fig. 1 shows that points obtained by diluting a pooled sample of mouse plasma with human plasma lie on the curve obtained using rat growth standard in human plasma in the range 5 to $50 \mathrm{ng} / \mathrm{ml}$. In table 1 , recoveries obtained

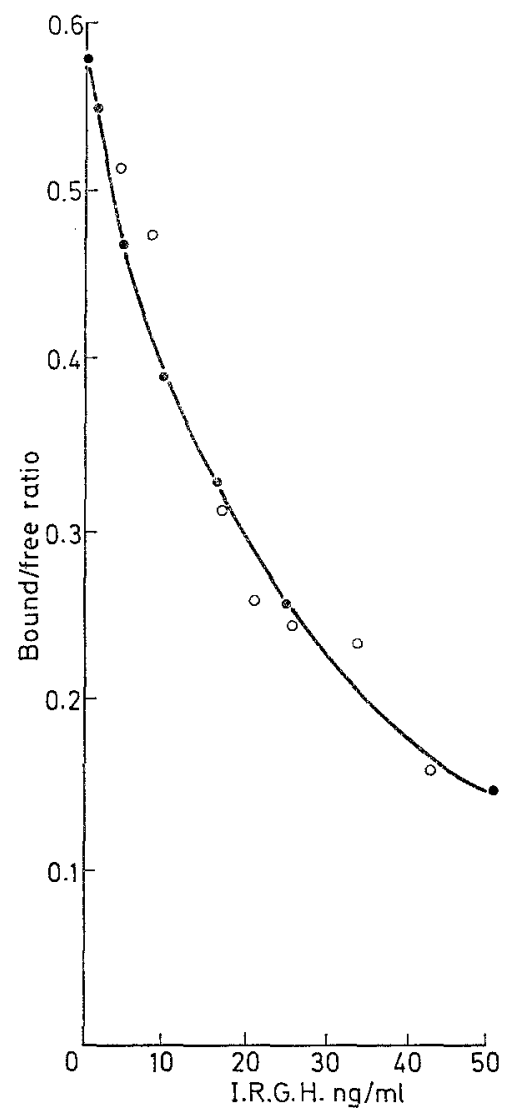

Fig. 1. Standard curve for rat growth hormone standard, showing that points obtained by diluting mouse plasma lie on this curve

standard points

$\bigcirc$ points obtained by diluting mouse plasma

Table 1. Values obtained for rat growth hormone standard added to a pooled sample of mouse plasma

\begin{tabular}{lcc}
\hline $\begin{array}{l}\text { Observed value } \\
\mathrm{ng} / \mathrm{ml}\end{array}$ & $\begin{array}{c}\text { Expected value } \\
\text { ng/ml }\end{array}$ & $\begin{array}{c}\text { Percentage } \\
\text { recovery }\end{array}$ \\
\hline 89 & 112.5 & 79 \\
59 & 62.5 & 94 \\
41 & 37.5 & 109 \\
26 & 28.5 & 91 \\
17 & 22.5 & 76 \\
15.5 & 17.5 & 89 \\
12.5 & 14.5 & 85 \\
\hline
\end{tabular}

after adding rat growth hormone standard to mouse plasma are shown. They ranged from $76 \%$ to $109 \%$ between 14.5 and $112.5 \mathrm{ng} / \mathrm{ml}$. The intra-assay coefficient of variation was $10 \%$ at $12.5 \mathrm{ng} / \mathrm{ml}$. The sensitivity of the assay routinely was $1 \mathrm{ng} / \mathrm{ml}$ or less. Non-specific binding in the system tended to be high, being 15 to $20 \%$ in human plasma, and 5 to $10 \%$ higher in mouse plasma. 
The values quoted subsequently for plasma IRGH refer to the weight of rat growth hormone standard preparation equivalent immunologically to the mouse growth hormone.

\section{Results}

1. Plasma IRGH in the NZO mice and in the control strain. For the age range studied, age did not affect plasma IRGH, as shown in Fig. 2. Mice of different ages were therefore considered together.

The plasma IRGH values obtained after an overnight fast are shown in Fig. 3 and those obtained after a three-hour fast are shown in Fig. 4 . The variance was

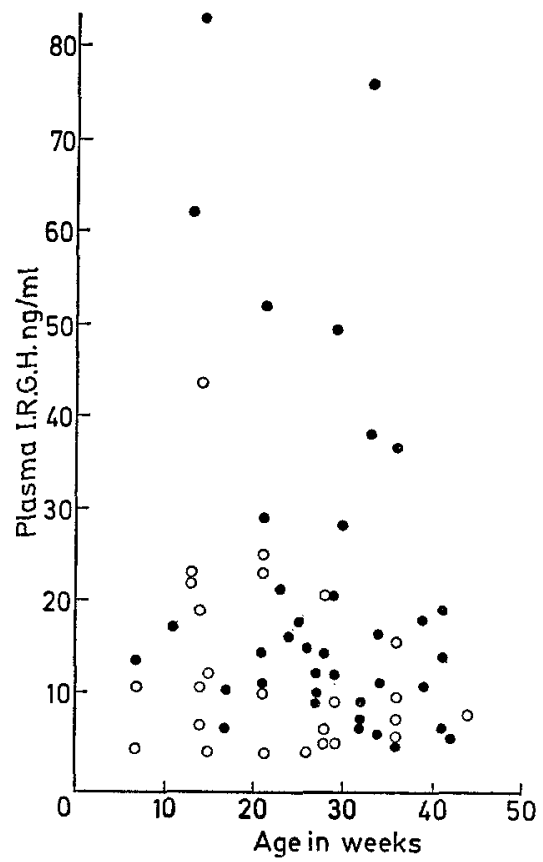

Fig. 2. Plasma IRGH after a three-hour fast plotted against age. Each point represents the plasma IRGH in a pooled sample from 2-4 littermates of the same sex - NZO mice $O \mathrm{C}_{57} \mathrm{~B}$ mice

For NZO mice $r=-0.28, p>0.05$. For $\mathrm{C}_{57} \mathrm{~B}$ mice $r=$ $-0.27, p>0.05$. A similar lack of association between plasma IRGH and age was found using values obtained after an overnight fast

significantly greater in the NZO mice under both conditions $(F=1.5, p<0.01$, and $\mathrm{F}=3.8, p<0.01$ for the overnight fast and three-hour fast respectively, where $F$ is the variance ratio). It can be seen that there were some conspicuously high values obtained for a few of the NZO mice, but that the majority had similar plasma IRGH levels to those in the $\mathrm{C}_{57} \mathrm{~B}$ mice. For statistical comparison, logarithmic conversion was used to standardize the variances and to approximate a normal distribution. The $t$ test for unpaired data was then applied, and there was no statistically significant difference between the mean log values of plasma IRGH for the NZO and $\mathrm{C}_{57} \mathrm{~B}$ mice, both after an over-

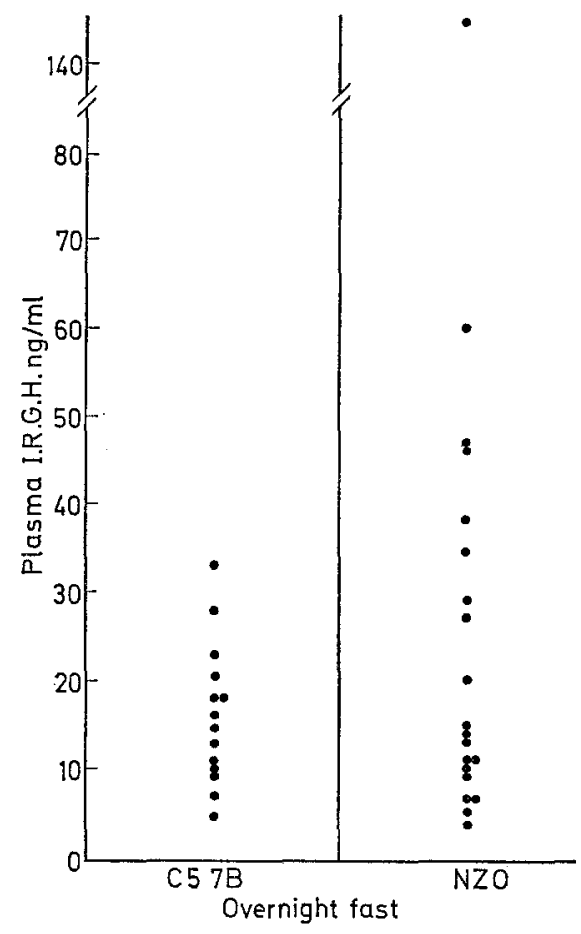

Fig. 3. Plasma IRGH after an overnight fast. Each point represents the plasma IRGH in a pooled sample from $2-4$ littermates of the same sex

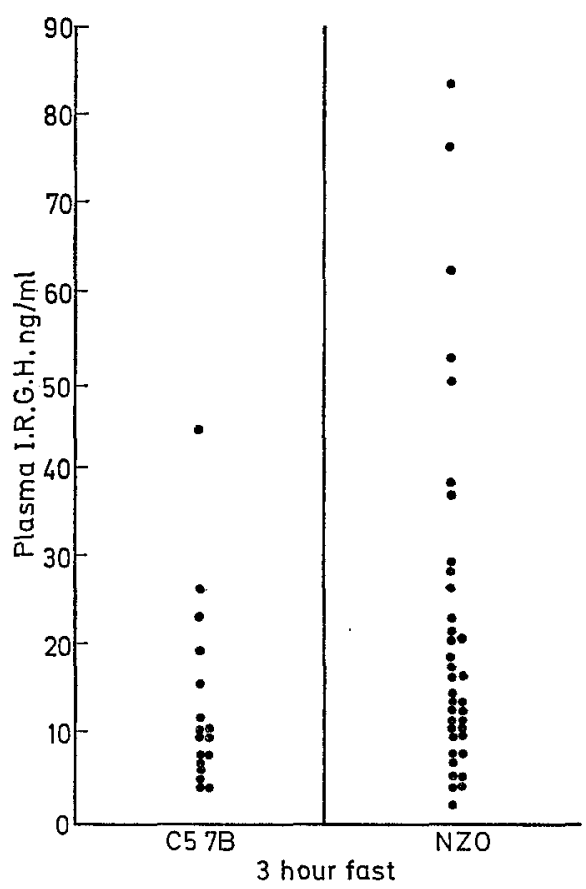

Fig. 4. Plasma IRGH after a three-hour fast. Each point represents the plasma IRGH in a pooled sample from $2-4$ littermates of the same sex

night fast and after a three-hour fast $(t=0.69$ and $t=1.84$ respectively).

The mean blood sugar concentration $( \pm$ SEM) for 
NZO mice after an overnight fast was $105.4 \pm 3.6 \mathrm{mg} /$ $100 \mathrm{ml}$ and this value was slightly higher than the mean concentration of $91.8 \pm 3.3 \mathrm{mg}$ per $100 \mathrm{ml}$ for the $\mathrm{C}_{57} \mathrm{~B}$ mice $(t=2.73, p<0.01)$. After a $3 \mathrm{~h}$ fast, the mean concentration was $152.9 \pm 3.8 \mathrm{mg} / 100 \mathrm{ml}$ compared. with $140.9 \pm 2.9 \mathrm{mg} / 100 \mathrm{ml}$ for the $\mathrm{C}_{57} \mathrm{~B}$ mice $(t=3.55$, $p<0.02$ ).

2. Effect of administered glucose on plasma IRGH. The mean plasma IRGH for the 7 groups of $\mathrm{C}_{57} \mathrm{~B}$ mice and 12 groups of NZO mice following glucose administration, is shown in figure 5 , and the mean blood sugar levels at the corresponding times are shown in Fig. 6. It is apparent that in both strains there is a rapid suppression of plasma IRGH apparent 5 min after

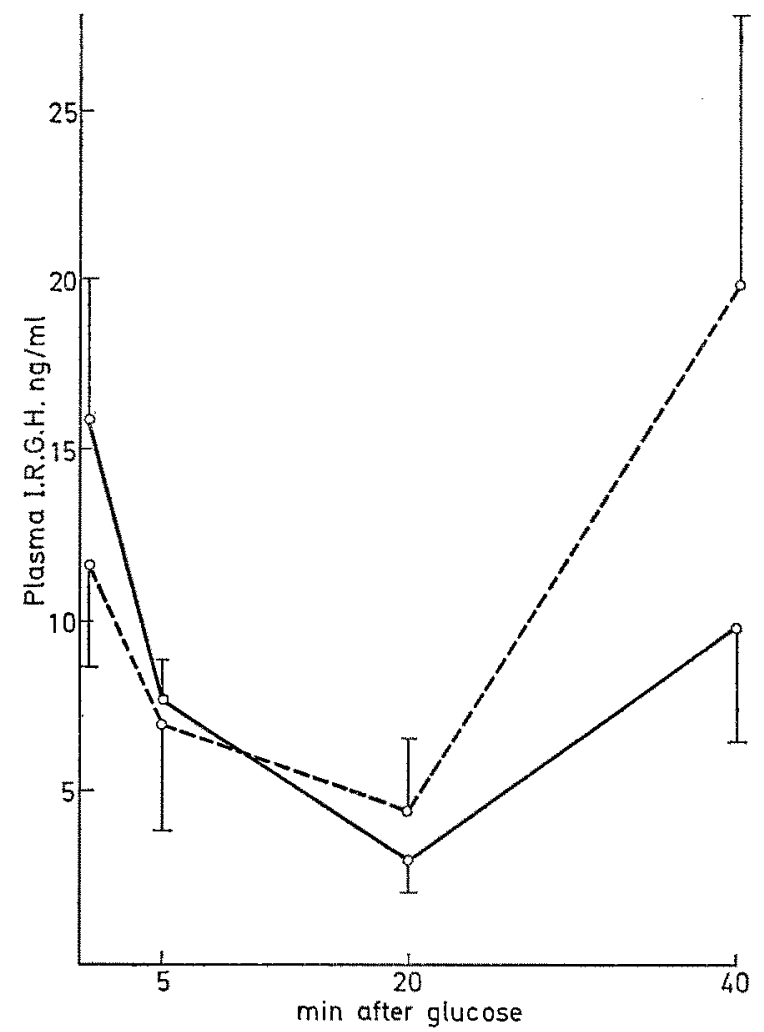

Fig. 5. Plasma IRGH following intraperitoneal glucose $[(2 \mathrm{mg} / \mathrm{g})$. The mean values and SEM are shown $\mathrm{O}-\mathrm{O} \mathrm{NZO}$

O...... $\mathrm{C}_{57} \mathrm{~B}$

glueose administration. The suppression was similar in both strains though it tended to be more complete and prolonged in the NZO mice. A fall in plasma IRGH of at least $33 \%$, and in most cases greater than $50 \%$, was observed. without exception in every age group tested at 5 or $20 \mathrm{~min}$ after the glucose injection. The plasma IRGH in the NZO mice at $5 \mathrm{~min}, 20 \mathrm{~min}$ and $40 \mathrm{~min}$ after the intraperitoneal glucose load was significantly lower than prior to the glucose $(p<0.02$, $<0.01,<0.01$ respectively - paired $t$ test). The rise in blood sugar was significantly greater and more

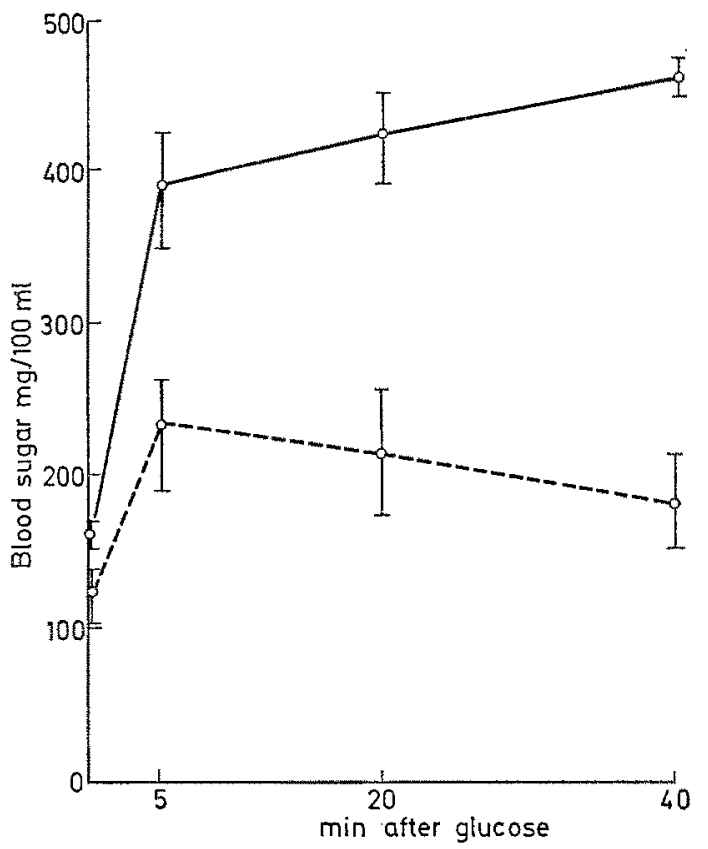

Fig. 6. Blood sugar following intraperitoneal glucose $(2 \mathrm{mg} / \mathrm{g})$. The mean values and SEM are shown $\mathrm{O}-\mathrm{O} \mathrm{NZO}_{\mathrm{C}} \mathrm{B}$

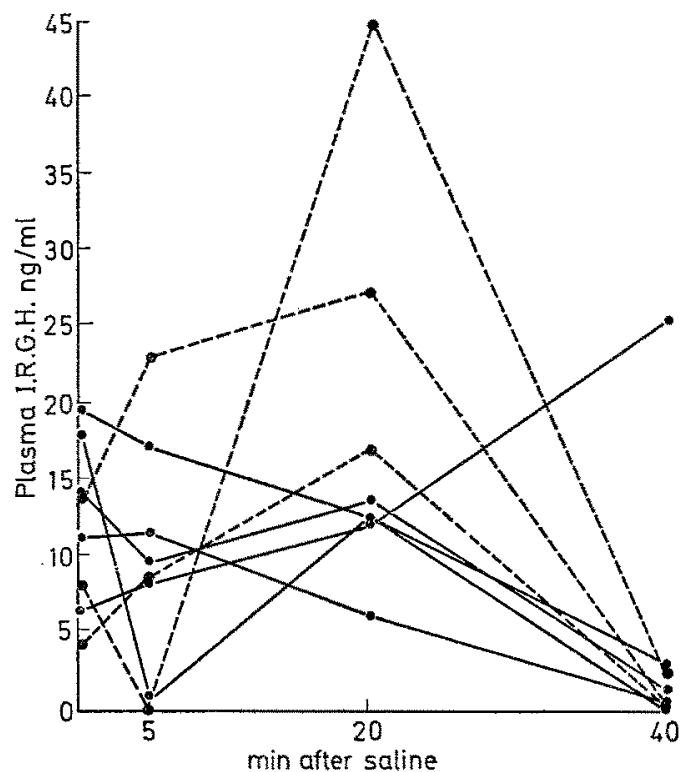

Fig. 7. Plasma IRGH for individual groups of mice following the injection of $0.9 \%$ saline $-\ldots \ldots . \mathrm{C}_{57} \mathrm{~B}$

sustained in the NZO mice than in the $\mathrm{C}_{57} \mathrm{~B}$ mice with this glucose load (Fig. 6).

In the control experiments in which $0.9 \%$ saline was injected instead of glucose, wide fluctuations were seen in the individual plasma IRGH levels (Fig. 7) despite relatively stable blood sugar levels (Fig. 8). 
However, there was no tendency towards suppression of plasma growth hormone at 5 and 20 min following the saline injection in either strain. In fact, in the $\mathrm{C}_{57} \mathrm{~B}$ mice there was a rise in plasma IRGH at $20 \mathrm{~min}$, followed by a fall at $40 \mathrm{~min}$. In both strains, the

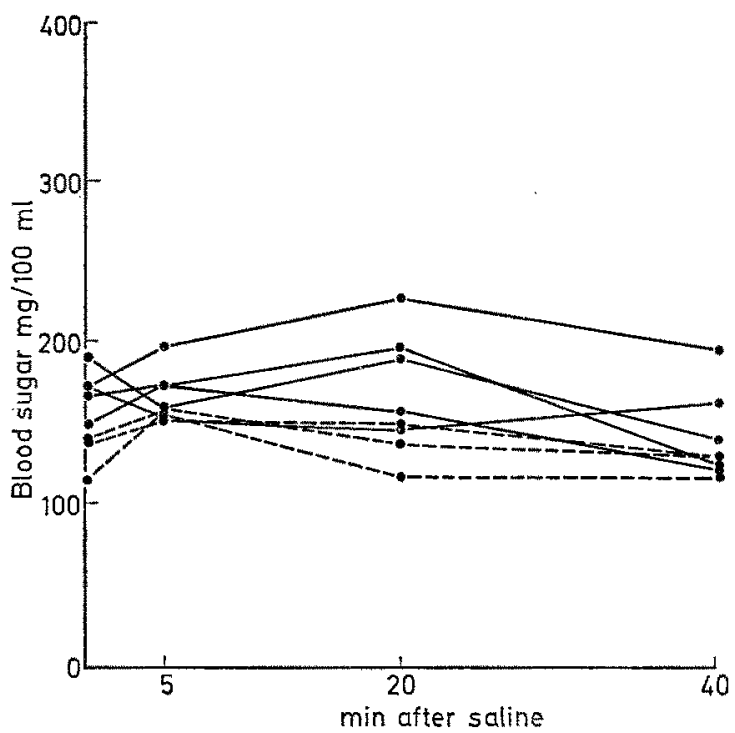

Fig. 8. Blood sugar for individual groups of mice following -..... $\mathrm{C}_{57} \mathrm{BO}$ the injection of $0.9 \%$ saline

plasma IRGH 20 min after the glucose was significantly lower than after the saline injection $(p<0.001$ for $\mathrm{NZO}$ mice, $p<0.01$ for $\mathrm{C}_{57} \mathrm{~B}$ mice) .

\section{Discussion}

Obesity $[1,4]$, carbohydrate intolerance $[4,10]$, hyperinsulinaemia $[10,15]$ and insulin resistance $[2,4]$ have been well documented in the NZO mouse. However the cause and mechanism of these abnormalities remain uncertain. The metabolic disorder appears similar to that in the ob-ob strain [16] and in the KK strain [13]. Herbai et al. have recently reported [7] that there is an increased rate of incorporation of labelled sulphate into the costal cartilage of obese-hyperglycaemic mice of the ob-ob strain. They have suggested that this may be associated with increased growth hormone activity, but could not exclude raised plasma insulin as a possible cause. Herbai [6] has also shown that hypophysectomy reversed the weight gain of these animals, but whether this was an effect on growth hormone production or on hypothalamic appetite regulatory centres is unknown. Nakamura et al. [13] reported increased pituitary growth hormone content using gel electrophoresis in the $\mathrm{KK}$ strain, but no extrapolation can be drawn to the plasma level of growth hormone.
The validity of the radioimmunoassay technique described for mouse growth hormone using antisera to rat growth hormone and rat growth hormone tracer has been established. Non-specifie binding in the system was quite high, but the problem of large and variable degrees of non-specific binding in different plasmas, recently described for rat serum using the dextran-charcoal method [12] was not encountered. The specificity of an assay system using rat growth hormone tracer and antiserum has been assessed by other workers [3] and no significant binding was demonstrated with other rat pituitary hormones. There was no significant sex or age difference in plasma IRGH within the strains under the conditions studied, so males and females of different ages were considered together. A possible effect of repeated trauma or anaesthesia [14, 17] was avoided by performing bleeds at different periods after glucose on separate days with the sample taken within $\mathbf{4 5} \mathrm{sec}$ of the commencement of the ether anaesthetic. The suppression in plasma growth hormone was shown to be due to the hyperglycaemia and not to the experimental procedure, by control experiments using intraperitoneal saline injections, where no similar early suppression of plasma IRGH was observed. The wide variation in plasma IRGH following saline reflects the lability of growth hormone secretion rate, and could not be accounted for by changes in blood sugar levels.

Apart from significantly greater variability in the NZO mice and some occasionally very high values, there was little difference in the levels of plasma IRGH in the two strains of mice. Blood sugar levels under basal conditions were slightly higher in the NZO mice than in the $\mathrm{C}_{57} \mathrm{~B}$ mice, but the levels were comparable and the slight difference would not be expected to influence the plasma IRGH. The reason for the greater variability in the plasma IRGH in the NZO mice is not clear, although a large degree of variability is also noted in body weight and glucose tolerance in different animals of this strain [4]. A wide range of fluctuations in plasma IRGH has been observed in mice by other workers [11], and probably represents spontaneous bursts of growth hormone secretion. More significantly, plasma IRGH was suppressed dramatically following glucose administration in both strains of mice. This phenomenon has recently also been described in rats [17], and contrasts with the reported lack of rise of plasma IRGH in response to hypoglyeaemia in rats [5] and mice [11]. Thus plasma IRGH responds in a qualitatively identical manner to administration of glucose and induced hyperglycaemia in both strains. Although this stimulus is an artificial one, it tests the competence of one homeostatic mechanism and reveals it to be functioning normally. This, together with the comparable basal levels, makes it most unlikely that pathological secretion of growth hormone from the pituitary is responsible for the metabolic abnormalities in the NZO mouse.

However, immunological activity does not neces- 
sarily parallel biological activity [5], and the possibility that some biologically active but immunologically inactive fragment of growth hormone is being produced in excess cannot be completely excluded. Moreover, results in the NZO strain of obese-hyperglycaemic mice cannot necessarily be extended to other strains, although the metabolic abnormalities appear similar.

Acknowledgements: The rat growth hormone was kindly provided by the National Institute of Arthritis and Metabolic Disease, Rat Pituitary Hormone Program. The Walter and Eliza Hall Institute of Medical Research, Royal Melbourne Hospital, generously made NZO mice available for study. The work was performed with the aid of grants from the Victor Hurley Fund for Medical Research, Royal Molbourne Hospital and the National Health and Medical Research Council. The guidance and advice of Dr. F.I.R. Martin and Professor R.R.H. Lovell were appreciated and Mrs. Bronwynlee Watson provided technical assistance.

\section{References}

1. Bielschowsky, M., Bielschowsky, F.: A new strain of mice with hereditary obesity. Proc. Univ. Otago med. Sch. 31, 29-31 (1953).

2. - - The New Zealand strain of obese mice. Their response to stilboestrol and to insulin. Aust. J. exp. Biol. med. Sei. 34, 181-198 (1956).

3. Birge, C.A., Peake, G.T., Mariz, I.K., Daughaday, W.H.: Radioimmunoassayable growth hormone in the rat pituitary gland: effects of age, sex and hormonal state. Endocrinology 81, 195-204 (1967).

4. Crofford, O.B., Davis, C.K.: Growth characteristios, glucose tolerance and insulin sensitivity of New Zealand obese mice. Metabolism 14, 271-280 (1965).

5. Garcia, J.F., Geschwind, I.I.: Investigation of growth hormone secretion in selected mammalian species. In Pecile, A., and Müller, E.E. (eds.). Inter. national Symposium on Growth Hormone, Excerpta Med., Int. Congr. Ser. 158, 267-291 (1968).

6. Herbai, G.: Weight loss in obese-hyperglycaemic and normal mice following transauricular hypophysectomy by a modified technique. Acta endocr. (Kbh.) 65, $712-722(1970)$.

7. - Westman, S., Hellerstrom, C.: The growth hormo. ne dependent incorporation of sulphate into the costal cartilage of obese-hypoglycaemic mice of different ages. Acta endocr. (Kbh.) 64, 415-420 (1970).

8. Hunter, W.M., Greenwood, F.C.: Preparation of Iodine-131 labelled human growth hormone in plasma Nature (London) 194, 495-496 (1962).

9. Jacobs, H.S.: Use of activated charcoal in the radioimmunoassay of human growth hormone in plasma. J. clin. Path. 22, 710-717 (1969).

10. Larkins, R.G.: Glucose tolerance, plasma insulin, plasma growth hormone and pattern of insulin release in the NZO mouse. Proc. Aust. Soc. Med. Res. 2, 357 (1970).

11. Müller, E.E., Miedico, D., Giostina, G., Cocchi, D.: Ineffectiveness of hypoglycaemia, cold exposure and fasting in stimulating growth hormone secretion in the mouse. Endocrinology 88, 345-350 (1971).

12. Nadeau, A., Zahnd, G.: Methodological aspects related to the immunoassay of growth hormone in rat serum (abstr.). Diabetologia 5, 58 (1969).

13. Nakamura, M., Yamada, L.: Studies on a diabetio (KK) strain of the mouse. Diabetologia $3,212-221$ (1967).

14. Schalch, D.S., Reichlin, S.: Plasma growth hormone concentration in the rat determined by radioimmuno. assay: influence of sex, pregnancy, lactation, anaesthesia, hypophysectomy and extrasellar pituitary transplants. Endocrinology 79, 275-280 (1966).

15. Sneyd, J.G.T.: Pancreatic and serum insulin in the New Zealand strain of obese mice. J. Endocr. 28, $163-172$ (1964).

16. Stauffacher, W., Lambert, A. E., Vecchio, D., Renold, A.E.: Measurements of insulin activities in pancreas and serum of mice with spontaneous ("obese" and "New Zealand obese") and induced (gold thioglucose) obesity and hyperglycaemia with considerations on the pathogenesis of the spontaneous syndrome. Dia. betologia 3, 230-237 (1967).

17. Takahashi, K., Daughaday, W.H., Kipnis, D.M.: Regulation of immunoreactive growth hormone secretion in male rats. Endocrinology 88, 909-917 (1971).

18. Yalow, R.S., Berson, S.A.: Preparation of high specificactivity ${ }^{131}$ I-labelled hormones. Use in radioimmunoassay of hormones in plasma. Radioactive Pharmaceuticals, AEC Symposium Series No. 6 CONF $651111,265-280(1966)$.

Dr. R.G. Larkins

University of Melbourne

Dept. of Medicine

Royal Melboume Hospital

Victoria, Australia 